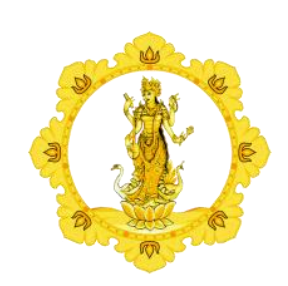

KALANGWAN

JURNAL PENDIDIKAN AGAMA, BAHASA DAN SASTRA

Vol. 11 No. 1 Maret 2021

\begin{tabular}{|c|c|l|}
\hline p-ISSN : 1979-634X & e-ISSN : 2686-0252 & http://ejournal.ihdn.ac.id/index.php/Kalangwan \\
\hline
\end{tabular}

\title{
KEBERTAHANAN TARI REJANG SUTRI DI DESA BATUAN KECAMATAN SUKAWATI KABUPATEN GIANYAR (Perspektif Sat Cit Ananda)
}

\author{
Oleh : \\ I Made Sukariawan \\ Universitas Hindu Negeri I Gusti Bagus Sugriwa Denpasar \\ E-mail: madesukariawan@uhnsugriwa.ac.id
}

Diterima 26 Januari 2021, direvisi 29 Januari 2021, diterbitkan 31 Maret 2021

\begin{abstract}
Rejang Sutri dance is different from other Rejang dances. The Rejang Sutri dance in Batuan Village, Sukawati District, Gianyar Regency has uniqueness that does not exist in other villages, this dance is specially performed at the beginning of the Sasih Kelima to the end of Sasih Kesanga at Pengrupukan and danced by women who live in environment of Batuan Village, Sukawati Gianyar. The dancers have no age limit, have links to Hinduism and are the cultural identity of Batuan Village. In addition, the Rejang Sutri dance is a form of community appreciation of one of the manifestations of Ida Sang Hyang Widhi Wasa / God. Traditionally, the Rejang Sutri dance has survived to this day. This research is entitled: Resilience of Rejang Sutri Dance in Batuan Village, Sukawati District, Gianyar Regency (Sat, Cit, Ananda Perspective).

The problems studied namely Why is the Rejang Sutri Dance in Batuan Village, Sukawati District, Gianyar Regency still surviving, Who contributed to maintaining Rejang Sutri Dance in Batuan Village, Sukawati District, Gianyar Regency, How do you maintain Rejang Sutri Dance in Batuan Village, Sukawati District, Gianyar Regency. The above problems will be examined using several theories. The theories used are religious theory, structural functional theory, and constructive education theory. In addition, in obtaining and analyzing data, several methods are used, namely the method of observation, interviews and document study. This type of research is qualitative and described by descriptive methods, in order to obtain a comprehensive conclusion.

Based on the results of the analysis and discussion of the results of the research, it can be concluded as follows: (1) The persistence of the Rejang Sutri dance in Batuan Village is inseparable from the beliefs of the people of Batuan Village and making the Rejang Sutri dance
\end{abstract}


as Sradha Bhakti for the people of Batuan Village where the relationship of belief in God is true truth or Sat or Satyam which is manifested in the form of sacred offerings, namely the Rejang Sutri dance, the people of Batuan Village believe that by making art an offering and its yadnya to get closer to God (Ida Sang Hyang Widhi Wasa). In accordance with the basis of Hindu religious beliefs known as Srada which consists of five parts, namely Panca Srada. One of these srada which is closely related is the first srada, namely believing in the existence of Brahman. The people of Batuan Village believe that the performance of the Rejang Sutri dance is a means of offering that can reject reinforcements or ward off disease outbreaks. So that the Rejang Sutri dance still survives because it embraces Sat or Satyam which means true truth.

(2) Contributing to the survival of the Rejang Sutri dance in Batuan Village is Prajuru Desa Adat Batuan as a supporter of the Rejang Sutri dance, which in an effort to preserve the Rejang Sutri dance has been contained in the Awig-awig of Batuan Traditional Village and has become an agreement with all Krama Batuan Traditional Village and its members. the community as supporters of the Rejang Sutri dance in its sustainability. Because the Rejang Sutri dance is a cultural heritage of sacred arts in Batuan Village. So with the performance of the Rejang Sutri dance in Batuan Village, the people of Batuan Village have supported the sustainability of the Rejang Sutri dance as a sacred and sacred offering that places Siwam or Cit which means purity, honesty, honesty as very important things and cannot be separated from Satyam or Sat who meaning true truth as well as related to Sundaram or Ananda which means beauty, happiness which the people of Batuan Village manifest in the Rejang Sutri dance performance.

(3) The way to maintain the Rejang Sutri dance in Batuan Village is by means of inheritance from generation to generation because the Rejang Sutri dance contains aspects of repelling reinforcements, aspects of ritual / ceremony, and aspects of beauty related to movement, composition, costumes, arenas and aspects of happiness in survival. Rejang Sutri dance where the people of Batuan Village still maintain the Rejang Sutri dance because it is closely related to aspects of Satyam or Sat (truth), Siwam or Cit (holiness) and Sundaram or Ananda (beauty / happiness). Because in sacred offerings towards the truth a happiness is achieved from the people of Batuan Village, so that they live in safety, prosperity and peace.

Keywords: Resilience, Rejang Sutri Dance.

\section{PENDAHULUAN}

Religi dan seni di Indonesia khususnya di Bali mempunyai pengaruh yang sangat besar terhadap kehidupan masyarakat. Kedua hal tersebut saling berhubungan antara yang satu dengan yang lainnya. Ketika religi dijalankan, maka senipun secara otomatis ikut mendampingi jalannya suatu kegiatan religi. Begitu pula halnya ketika seni dipentaskan, maka relegipun ikut dijalankan . Bila melihat perilaku kesenian di Bali, kebanyakan didasari oleh tuntutan filosofi Agama Hindu dan hal ini sangat sesuai dengan masuknya Agama Hindu ke Bali. Kesenian sebagai unsur kebudayaan Bali dirasakan telah memberikan kontribusi yang besar kepada masyarakat dibidang jasmani dan rohani.
Tanpa disadari pembangunan karakter masyarakat Bali banyak ditentukan oleh keikutsertaan masyarakat Bali dalam aktivitas berkesenian (Triguna, $2003: 1$ ).

Umat Hindu memanfaatkan kebudayaan dan kepercayaan lokal sebagai media untuk pengejewantahan ajaran Agama Hindu. Upakara, tempat-tempat pemujaan, nyanyian (dharmagita), sastra agama, adalah beberapa bentuk kebudayaan yang bermuatan nilai religius. Kebudayaan itu dari waktu ke waktu, dan dari suatu tempat ke tempat yang lain, mengalami perubahan, perbedaanperbedaan, namun hakikat dan inti ajaran agama yang termuat di dalamnya adalah sama. Bentuk kehidupan bersama dengan tata tertibnya selalu menjadi wadah pelaksanaan 
hidup beragama Hindu di Bali seperti : keluarga, sekaa, banjar dan desa adat. Pelaksanaan hidup beragama juga selalu direalisasikan melalui kebudayaan. Hal ini tampak pada tempat-tempat pemujaan, sarana pemujaan, pakaian, sikap memuja, dan lainlainnya. Agama Hindu menuntun sifat-sifat dasar manusia menjadi sifat yang mulia dengan mewujudkan ajaran tattwa dalam tuntunan hidup di dunia ini. Keyakinan atau sraddha kepada Tuhan Yang Maha Esa selain direalisasikan dalam ibadah agama dan dalam bentuk bhakti kepada Tuhan (Sura, 1994 : 14).

Agama Hindu mengenal adanya lima macam jenis yadnya atau yang sering disebut dengan dengan Panca Yadnya yang terdiri atas Dewa Yadnya, Rsi Yadnya, Pitra Yadnya, Manusa Yadnya dan Butha Yadnya. Dalam pelaksanaan kelima Yadnya ini besifat wajib bagi umat Hindu. Yadnya adalah koban suci yang dilakukan dengan senang hati, tulus iklas, dan merupakan salah satu kewajiban bgi umat Hindu di Bali. Dasar hukum dari melaksanakan Yadnya adalah Tri Rna, yaitu tiga hutang manusia menurut ajaran agama Hindu. Tri Rna, yaitu (1) Dewa Rna, yaitu hutang kepada para Dewa sebagai pencipta, pemelihara, dan pelebur kehidupan ini, (2) Rsi $R n a$, yaitu hutang kepada para Rsi (Guru) yang telah memberikan tuntunan tattwa, susila, acara, dan (3) Pitra Rna, yaitu hutang kepada Pitara (leluhur) yang telah melahirkan dan memelihara kita di dunia ini (Tim Penyusun, $2003: 10$ ).

Atas dasar tiga hutang (Tri Rna) tersebut di atas, maka masyarakat Bali dengan dijiwai oleh ajaran agama Hindu, melakukan aktivitas dengan berbagai tradisi, untuk mengekspresikan dirinya kepada tiga hutang itu. Secara simbolik dalam bentuk upacara dengan upakara dan didukung oleh tarian yang dimiliki oleh adat dan budaya dalam berbagai kehidupannya. Demikian pula pada kehidupan umat Hindu di Bali dalam pengimplementasiannya terhadap ajaran agama dan tradisinya tidak pernah terlepas dari Tri Hita Karana, sebagaimana disebukan di atas, yaitu tiga unsur hubungan yang harmonis untuk mencapai kesejahteraan diantaranya : hubungan harmonis diantara manusia dengan Tuhan (parhyangan), hubungan manusia dengan manusia lainnya (pawongan), dan hubungan manusia dengan alam lingkungannya (palemahan). Di samping itu pula dipengaruhi oleh konsep desa, kala, dan patra yaitu tempat, waktu dan keadaan (tim penyusun, 1993 : 15).

Di Bali pelaksanaan kelima yadnya tersebut selalu disertai dengan tarian keagamaan yang bermacam- macam. Tari di Bali kebanyakan diguanakan dalam upacaraupacara kegamaan, tetapi ada juga yang digunakan hanya sebagai tontonan saja dalam acara-acara penyambutan suatu kegiatan yang bersifat formal. Tari Bali secara garis besarnya dapat diklasifikasikan menjadi tiga jenis, yaitu tari Wali, yaitu tari yang bersifat sakral dan hanya digunakan dalam upacara Panca Yadnya, sedangkan tari Bebali adalah tari-tarian yag hanya dipersembahkan dalam ragkaian upacara Panca Yadnya maupun dalam kaitannya dengan fungsi hiburan masyarakat (Titib, 2003 : 158).

Tari Rejang Sutri di Desa Batuan memiliki keunikan-keunikan yang tidak terdapat di desa lain, tari ini dipentaskan khusus pada awal Sasih Kelima sampai dengan akhir Sasih Kesanga pada saat Pengrupukan dan ditarikan oleh wanitawanita yang tinggal di lingkungan Desa Batuan Sukawati Gianyar. Penarinya tidak ada batas usia dan merupakan identitas kebudayaan Desa Batuan sehingga kebertahanannya dapat berlanjut.

Berdasarkan uraian tersebut di atas, tari Rejang Sutri sangat menarik dan memiliki keunikan sehingga perlu untuk diteliti, di samping tari Rejang Sutri ini sebagai bentuk penghayatan masyarakat terhadap manifestasi dari Ida Sang Hyang Widhi Wasa. Secara tradisi tari Rejang Sutri masih bertahan sampai saat ini. Oleh karena itu, perlu dianalisis lebih dalam mengenai mengapa tari Rejang Sutri masih bertahan, siapa yang berkontribusi mempertahankan dan bagimanakah caranya mempertahankannya. Dengan demikian peneliti ingin mengangkat permasalahan tersebut dalam sebuah judul penelitian yaitu "Kebertahanan Tari Rejang Sutri di Desa Batuan, Kecamatan Sukawati, 
Kabupaten Gianyar (Perspektif Sat Cit Ananda)".

\section{HASIL DAN PEMBAHASAN \\ 2.1 Masih Bertahannya Tari Rejang Sutri di Desa Batuan}

Bertahannya tari Rejang Sutri di Desa

Batuan tidak terlepas dari keyakinan masyarakat. Puncak emosi keagamaan setiap manusia sesungguhnya berada pada kerinduan pikiran manusia yang memerlukan kebutuhan religius. Rasa religius dilaksanakan secara berbeda-beda tergantung agama yang dianutnya. Masyarakat Desa Batuan dalam hal ini menggunakan tari Rejang Sutri sebagai media untuk memenuhi kerinduan rasa religiusnya.

\subsubsection{Kepercayaan Masyarakat Desa Batuan}

Agama Hindu yang pada dasarnya disebut Dharma memuat dasar ajaran yang menjadi ciri khas dari pada agama itu sendiri. Dasar-dasar ajaran yang kemudian dikenal oleh agama Hindu disebut dengan Sradha.

Umat Hindu memiliki Sradha atau keyakinan yang terbagi atas lima bagian yang biasa disebut dengan Panca Sradha. Dharma atau kebenaran, kebajikan merupakan landasan umat Hindu untuk melakukan suatu perbuatan, dengan berlandaskan dharma maka ketenangan di dalam dunia akan tercapai.

Satyam atau Sat artinya kebenaran sejati. Krama Desa Batuan sebagian besar belum terlalu mengerti mengenai konsep Panca Sradha akan tetapi masyarakat Desa Batuan percaya terhadap keberadaan Tuhan sebagai hakekat kebenaran sejati. Tuhan sebagai satu-satunya tempat berlindung, berserah diri terhadap segala persoalan yang berada di luar batas dan di luar nalar kemampuan manusia sehingga untuk menjawab segala persoalan tersebut manusia berusaha mendekatkan diri kepada Tuhan melalui keyakinan dan ritual.

\subsubsection{Tari Rejang Sutri sebagai Sradha Bhakti Masyarakat Desa Batuan}

Sradha berarti keyakinan/kepercayaan sebagai cikal bakal dari penguatan beragama. Maka dalam agama Hindu berbentuk keyakinan. Bhakti dalam kehidupan seharihari sering kita dengar dan aplikasian dalam kehidupan sehari-hari. Secara etimilogi kata bhakti dalam Kamus Besar Bahasa Indonesia (1997 : 82) diartian tunduk dan hormat atau perbuatan yang menyatakan setia (kasih, hormat dan tunduk). Karena bhakti berarti tunduk, hormat, dan setia maka dalam berbagai aspek kehidupan dipakai sebuah pernyataan penyampaian rasa bhakti itu sendiri, seperti : bhakti kepada Tuhan Yang Maha Esa dan para leluhur (tanda penyampaian rasa hormat dan tunduk), bhakti kepada nusa dan bangsa, bhakti kepada orang tua, bhakti kepada guru, bhakti kepada raja atau pemimpin. Kata bhakti berarti bagian, pembagian, penghormatan, bhakti, kesetiaan (Tim penyusun, $1986: 269$ ).

Setelah pelaksanaan tari Rejang Sutri umat merasakan suatu kedamaian serta ketentraman dalam diri individu maupun keluarga sehingga dengan apa yang dirasakan tersebut maka umat merasa yakin akan suatu kekuatan dari sesuwunan Bathara-Bhatari sehingga wujud bhakti umat kehadapan Tuhan lebih tebal (Jro Mangku I Ketut Suantika, wawancara tanggal 20 Juni 2020) seperti apa yang tertuang dalam Bhagavadgita II. 66 sebagai berikut :

Nāsti buddhir ayuktasya, Na cāyuktasya bhāvanā, Na cābhāvayatah sāntir, Asāntasya kutah sukham,

Terjemahan :

Orang yang tidak mempunyai hubungan dengan Tuhan Yang Maha Kuasa, tidak mungkin memilki kecerdasan rohani dan pikiran yang mantap. Tanpa pikiran yang mantap tidak mungkin ada kedamaian, tanpa kedamaian bagaimana mungkin ada kebahagian (Pudja,1984: 67)

Masih bertahannya tari Rejang Sutri di Desa Batuan karena tari Rejang Sutri di Desa Batuan merupakan sradha bhakti masyarakat 
Desa Batuan. Sebagai salah satu cara atau jalan yang ditempuh masyarakat Desa Batuan dengan pementasan tari Rejang Sutri sebagai media atau alat untuk menghubungkan diri dan berlindung kepada Tuhan.

\subsection{Yang Berkontribusi Terhadap Bertahannya Tari Rejang Sutri di Desa Batuan}

Setiap anggota masyarakat yang sebagai pendukung pementasan tari Rejang Sutri adalah juga tidak dapat dipisahkan dengan sekaa tabuh atau mereka yang memainkan gambelan sebagai pengiring tari rejang Sutri. Setiap masyarakat pendukung memiliki keinginan untuk "gaturang ayah" sebagai perwujudan rasa bhakti kepada Tuhan sehingga dengan sendirinya mereka terlibat untuk dapat ngaturang ayah dan secara tidak langsung mereka telah berkotribusi dalam kebertahanan tari Rejang Sutri di Desa Batuan.

\subsubsection{Prajuru Desa Adat Batuan Sebagai Pendukung Tari Rejang Sutri}

Prajuru adalah pengurus Desa Adat/Pakraman yang melayani masyarakat dalam setiap banjar, desa adat maupun kelembagaan lainnya yang ada di Bali, karena secara hukum adat disebutkan, keberadaan lembaga-lembaga tersebut secara sosiologis masih dipelihara oleh masyarakat sebagai perwujudan budaya bangsa yang perlu diayomi dan dilestarikan.

Desa atau Kelurahan Batuan terdiri dari tujuh belas Banjar Dinas dan terbagi menjadi empat desa adat yaitu Desa Adat Batuan, Desa Adat Negara, Desa Adat Lantangidung dan Desa Adat Gerih. Desa Adat sebagai Desa Dresta adalah kesatuan masyarakat hukum adat di Provinsi Bali, yang mempunyai satu kesatuan tradisi dan tata krama pergaulan hidup masyarakat umat Hindu secara turuntemurun dalam ikatan Kahyangan Tiga yang mempunyai wilayah tertentu dan harta kekayaan sendiri serta berhak mengurus rumah tangganya sendiri (Tim Penyusun,1992:4).

Kepentingan-kepentingan Desa Adat ditangani oleh Prajuru Desa Adat yang terdiri dari beberapa orang dari Krama Desa itu sendiri. Di daerah Bali mengenai jenis, istilah dan jumlah Prajuru Desa Adat tidak seragam, melainkan tergantung dari tradisi yang hidup dan tertuang dalam Awig-awig Desa Adatnya. Desa Adat Batuan terdiri dari : 1. Desa Adat Batuan, 2. Desa Adat Negara, 3.Desa Adat Lantangidung, 4. Desa Adat Gerih.

Prajuru Desa Adat Batuan sangat berperan penting dalam usaha menjaga, melestarikan, meneruskan dan mempertahankan keberadaan tari Rejang Sutri di Desa Batuan. Prajuru Desa Adat Batuan memberikan ruang seluas-luasnya bagi masyarakat yang berniat gaturang ayah untuk menarikan tari Rejang Sutri tanpa membedakan status sosial karena memang penari yang menarikan tari Rejang Sutri tanpa batas usia, kalau sudah siap ngaturang ayah (Nyutri) menarikan Rejang Sutri yang telah tertuang dalam Awig-awig Desa Adat Batuan dan menjadi kesepakatan bersama seluruh Krama Desa Adat Batuan. (I Made Djabur, BA. Wawancara tanggal 27 Juni 2020).

Berdasarkan pemaparan di atas maka Prajuru Desa Adat Batuan sangat berkontribusi dalam mempertahankan keberlanjutan tari Rejang Sutri secara terusmenerus dari generasi ke generasi berikutnya sebagai kearifan lokal dan tari sakral warisan budaya adi luhung yang sangat lekat dengan kehidupan masyarakat Desa Batuan.

\subsubsection{Anggota Masyarakat Sebagai Pendukung Tari Rejang Sutri}

Desa Pakraman dalam pengertian ini menunjuk kepada suatu wilayah yang dihuni oleh penduduk yang beragama Hindu, kecuali di beberapa desa dalam kota atau desa-desa yang terletak di pinggir pantai yang penduduknya sudah heterogen dan terdiri dari berbagai umat beragama. Dherana (1982) dalam bukunya yang berjudul "Pembinaan Awig-Awig Desa Pakraman Dalam Tertib Masyarakat" mengatakan bahwa istilah desa mengandung dua pengertian, yaitu:

1. Secara Tradisional desa adalah merupakan perwujudan dari lembaga pakraman, yang dikenal dengan istilah "Desa Pakraman" 
2. Pengertian kedua adalah menunjuk pada adanya bentuk Desa Administratif yang eksistensinya tergantung pada kehendak penguasa daerah, yang disebut "Desa Dinas". (Dherana, 1982: 21)

Secara umum para penari dapat melibatkan diri dalam pementasan tari Rejang Sutri, terutama dalam jiwa mereka sebagai perwujudan dari srada bhakti, lascarya (tulus iklas), asas kebersamaan dan asas pengabdian sehingga kalau tidak dapat "ngayah" sepertinya ada perasaan bersalah dalam diri mereka.

Pementasan tari Rejang Sutri menciptakan rasa solidaritas yang tinggi diantara masyarakat, yakni "segilik seguluk selulung sebayantaka, paras paros sarpenaya”. Anggota masyarakat juga berkontribusi terhadap kebertahanan, kelestarian dan keberlangsungan secara turun-temurun "ngemagehang tur mikukuhin dresta sane sampun katami"'(mempertahankan warisan budaya kearifan lokal yang telah diwariskan). (Wawancara dengan I Made Djabur, BA. Tanggal 27 Juni 2020). Anggota masyarakat dalam hal ini termasuk penari tari Rejang Sutri dan Sekaa Gong yang mengiringi tari Rejang Sutri.

\subsubsection{Tari Rejang Sutri Sebagai Warisan Budaya Seni Sakral Desa Batuan}

Kesenian Bali merupakan ekpresi jiwa yang di dalamnya diikat oleh nilai-nilai sosial lainnya yang ada di Bali. Selanjutnya pernyataan ekpresi yang secara sosial dipantulkan maupun sebagai renungan dan kreasi, kesenian yang bersifat dinamis seperti pada mewujudkan dari bentuk-bentuk seni yang telah ada, maka perubahan itu dapat dilihat pada penambahan jumlah perwujudan dari lama menjadi baru sebagai akibat dari perkembangan (Bandem,1985: 15).

Tari Bali merupakan bagian terpenting dari kehidupan masyarakat Bali yang sudah diwarisi sejak zaman lampau yang menyebabkan bentuk-bentuk kesenian tersebut masih terpelihara samapai sekarang. Yang tak kalah pentingnya bahwa masyarakat Bali yang mayoritas memeluk agama Hindu ikut mendukung kesenian tersebut. Di Bali hampir tak ada satupun upacara keagamaan yang selesai tanpa ikut sertanya pertunjukan kesenian (Bandem,1996: 16).

Menurut I Wayan Wastika (Wawancara tanggal 10 Juli 2020) menyatakan bahwa Pementasan tari Rejang Sutri di Desa Batuan sebagai sarana persembahan merupakan warisan budaya seni sakral adi luhung masyarakat Desa Batuan. Tari Rejang Sutri sebagai warisan leluhur yang mengandung nilai kesucian atau $\mathrm{Cit}$ atau Siwam. Inilah sebagai landasan utama atau yang paling mendasar dari setiap persembahan adalah kesucian hati, cinta kasih dan keiklasan.

Berdasarkan pendapat informan di atas, dapat di pahami suatu hal yang menarik dan unik karena Tari Rejang Sutri hanya diadakan pada Sasih Kelima sampai dengan akhir Sasih Kesanga yang ditarikan oleh semua kalangan tanpa ada batas usia dan dengan gerakan tarian yang sangat sedehana namun memiliki makna dan filosofi yang sangat mendalam. Tari Rejang Sutri terus dipertahankan keberadaaanya mengingat tari Rejang Sutri sebagai warisan seni tari sakral yang adi luhung yang menyangkut aspek Siwam atau Cit atau kesucian itu sendiri.

\subsection{Cara Mempertahankan Tari Rejang Sutri di Desa Batuan}

Seni itu akan dapat tetap bertahan apabila didukung oleh para pendukungnya, jika pendukungnya tidak mendukung maka seni itu akan hilang kebertahananya. Seni itu didukung oleh para pendukungnya apabila dianggap berfungsi bagi para pendukungnya karena seni di Bali sangat lekat dengan kehidupan masyarakat Bali itu sendiri. Kebertahanan seni tari Rejang Sutri ini bagi masyarakat Desa Batuan tidak terlepas dari fungsi dan manfaat bagi kehidupan masyarakat Desa Batuan.

\subsubsection{Pewarisan Dari Generasi ke Generasi}

Pendidikan adalah usaha sadar dan terencana untuk mewujudkan suasana belajar dan proses pembelajaran agar peserta didik secara aktif mengembangkan potensi dirinya untuk memiliki kekuatan spiritual 
keagamaan, pengendalian diri, kepribadian, kecerdasan, ahlak mulia, serta ketrampilan yang diperlukan dirinya, masyarakat, bangsa dan negara (Pasal 1 : UU Sisdiknas No.20/2003). Kata pendidikan berasal dari bahasa Yunani yaitu Paedagogiec kata ini terdiri dari kata pais yang artinya anak, agogos berarti bimbingan, tuntunan dan iek artinya ilmu. "Paedagogiec berarti ilmu tentang cara membimbing atau menuntun anak" (Suwarno,1992: 1). Pendidikan adalah fenomena fundamental atau asasi dalam kehidupan manusia dimana ada kehidupan manusia, bagaimanapun juga disitu pasti ada pendidikan (Driyarkata, 1999: 32).

Konsep pendidikan dalam perspektif Hindu sangat dipentingkan, bahkan secara normatif telah diatur sedemikian rupa mulai dari masa kanak-kanak hingga menjelang ajal tiba yang bukan saja berguna di alam maya ini tetapi juga kelak setelah meninggal (widya castra sudharma dipanikang tri-bhuwana semeno prabhaswara). Di bagian lain Niti Sastra.V .1 menyebutkan:

Taki-takining sewaka guna widya Smara-wisaya rwang puluning ayuse Tengahi Tuwuh san-wacana gegon-ta Panilangin atmeng tanu paguroken Terjemahannya :

Semasih muda bersiap-siap untuk menuntut ilmu, Berumah tangga setelah berumur dua puluh tahun, Setengah umur kebenaran kata-kata hendaknya dipegang, Hanya untuk menunggalnya jiwa patut dihusahakan (Darmayasa, 1995: 37)

Dengan pemahaman diatas bahwa tingkat-tingkat pencapaian spiritual diawali oleh pendidikan sebelum menapak kehidupan selanjutnya sebagai grehasta, wanaprasta dan akhirnya sanyasin. Untuk mencapai kebebasan diketiga alam, maka pengetahuan (pendidikan) inilah menjadi dasarnya. Kejelasan ucapan, kemurnian tubuh, kesucian jiwa, semua dari ketiga hal ini adalah tujuan yang dituju oleh pendidikan (Radhakrishnan,2000: 23). Selanjutnya dalam Bhagawadgita IV.36 dinyatakan
Api cedasi pepebhyah, sarwebyha pāpakrittawah, sarwam jñāna plawenai'wa, wijina Samptariswa

Artinya :

Walupun seadainya engkau paling berdosa di antara pemikul dosa, dengan perahu ilmu pengetahuan (gunawidya) lautan dosa akan engkau sebrangi.

(Pudja,1993: 117).

Dengan demikian dapat dipahami bahwa pelaksanaan pementasan tari Rejang Sutri di Desa Batuan, dari aspek pendidikannya akan secara langsung terjadi proses pendidikan. Baik dari segi pelaksanaannya secara turun temurun akan dapat mendidik masyarakat serta mewariskannya dari generasi ke generasi berikutnya, Maka pelaksanaan pementasan tari Rejang Sutri di Desa Batuan akan tetap berkelanjutan secara terus-menerus dan tidak akan mengalami kepunahan.

\subsubsection{Aspek Penolak Bala Dalam Kebertahanan Tari Rejang Sutri}

Masyarakat Bali sangat dekat dengan pengaruh-pengaruh mistis, mereka sangat meyakini hal-hal yang bersifat metafisis. Sebagaimana halnya masyarakat Desa Batuan sangat percaya bahwa dalam pementasan tari Rejang Sutri merupakan sarana yang dapat menolak bala atau menangkal wabah penyakit. Sebagaimana yang dijelaskan oleh Jro Mangku Pura Puseh Desa Batuan, Jro Mangku I Wayan Suda sebagai informan peneliti adalah sebagai berikut: Timbulnya tari Rejang Sutri di Desa Batuan adalah karena rasa cemas masyarakat diganggu dan diserang penyakit. Timbulnya rasa cemas ini karena masyarakat setempat, percaya akan adanya I Gede Mecaling dari Nusa Penida, yang sewaktu-waktu akan datang untuk mengganggu ketentraman masyarakat Batuan. Kedatangan I Gede Mecaling untuk balas dendam atas kekalahannya melawan I Dewa Babi sewaktu I Gede Mecaling tinggal di Tegalinggah Banjar Jungut Desa Batuan. 
Sehubungan dengan ini di Bali ada suatu kepercayaan bahwa pada sasih keenem (bulan Desember) dikenal dengan saat-saat berjangkitnya bermacam-macam penyakit dan dirasakan sangat genting. Sehingga masyarakat Desa Batuan senantiasa memohon ke Pura Puseh Desa Batuan, agar masyarakat terhindar dari segala mara bahaya dan wabah penyakit. Sehingga pada suatu hari Ida Bhatara yang berstana di Pura Puseh Desa Batuan memberikan pawisik kepada Jro Mangku untuk menyuguhkan tarian Rejang Sutri dan Gocekan sebagai penyambutan datangnya Ida Ratu Gede Mecaling bersama pasukan makhluk halusnya ke Desa Batuan. Diharapkan dengan menonton tarian itu dapat meluluhkan dendam beliau.

Demikianlah asal mula timbulnya tari Rejang Sutri di Desa Batuan yang menjadi tradisi tari sakral bagi masyarakat Batuan sampai sekarang untuk memohon keselamatan pada saat-saat yang di sebut dengan musim Grubug. (Wawancara Jro Mangku I Wayan Suda, tanggal 3 Juli 2020).

\subsubsection{Aspek Ritual / Upacara Dalam Kebertahanan Tari Rejang Sutri}

Untuk mewujudkan rasa bhaktinya, maka manusia selalu berusaha dan berupaya untuk dapat mewujudkan rasa bhakti dan rasa kasihnya kepada Tuhan Sehubungan dengan pelaksanaan pementasan tari Rejang Sutri di Desa Batuan tidak bisa terlepas dari aspek ritual/upacara di dalam mendukung kebertahanan dan keberlanjutannya dari generasi ke generasi sampai dengan saat ini.

Menurut Ni Nyoman Waluh (Wawancara tangal 18 Juli 2020). Aspek ritual atau upacara dapat dirasakan oleh masyarakat ketika akan berlangsung upacara dari perencanaan pementasan tari Rejang Sutri pada awal Sasih Kelima sampai dengan berakhirnya upacara yaitu pada akhir Sasih Kesanga. Dari tahap persiapan, pelaksanaan, dan sampai berakhirnya pelaksanaan tari Rejang Sutri. Adapun cara pelaksanaan dari upacara tersebut adalah sebagai berikut. Melaksanakan upacara mecaru (Butha Yadnya), mengadakan Gocekan (sabungan ayam kecil atau ayam Gumerot), melakanakan pementasan tari Rejang Sutri.

Upacara mecaru (Butha Yadnya) dilakukan pada sore hari di Pura Desa, di tiaptiap persimpangan jalan di lingkungan masyarakat Batuan yang dilanjutkan dengan mecaru di tiap-tiap pintu gerbang pekarangan atau lebuh masing-masing anggota masyarakat. Pada saat ini juga diadakan gocekan di jaba Pura Desa sebagai rangkaian upacara mecaru (Buta Yadnya). Pada malam harinya baru di pertunjukkan tari Rejang Sutri, sebelum pertunjukan dimulai diawali dengan upacara menghaturkan sesajen berupa Pejati di Pura Desa dan di tempat berlangsungnya pertunjukan. Upacara mecaru (Butha Yadnya) hanya dilakukan pada tiap hari Kajeng Kliwon, Purnama, Tilem, sampai saat-saat upacara itu selesai. Gocekan dan pertunjukan tari Rejang Sutri ini dilaksanakan setiap hari pada sore hari dan malam hari, sampai saat-saat upacara selesai.

Dalam pelaksanaan pementasan tari Rejang Sutri aspek ritual/upacara dapat mendidik masyarakat serta mewariskannya dari generasi ke generasi berikutnya, untuk tetap melaksanakannya sebagai cetusan rasa bhakti kehadapan Tuhan dan juga dapat mewariskan nilai-nilai budaya yang luhur kepada generasi muda (teruna-teruni) dalam hal pembuatan sarana perlengkapan upacara maupun upakaranya.

Dalam Bhagawadgita Bab III sloka 16 disebutkan bahwa :

\section{Evam pravartitam cakram Nanuvartayatiha yah Aghayur indriyaramo Mogham partha sa jivati}

Artinya :

Orang yang tidak mengikuti sistim korban suci yang ditetapkan dalam Veda Pasti hidup dengan cara yang penuh dosa sia-sialah kehidupan orang seperti itu yang hanya hidup untuk memuaskan indria-indria (Pudja, 1984 : 80).

Berdasarkan kutipan di atas, maka dapat dipahami bahwa dengan mewariskan budaya 
yang luhur tersebut kepada generasi penerus maka pelaksanaan pementasan tari Rejang Sutri di Desa Batuan terutama dalam pembuatan sarana upakaranya akan tetap semarak dan tidak mengalami kelumpuhan. Lebih jauh dilaksanakan dalam bentuk pengendalian diri, baik dari segi material maupun spiritual dalam bentuk banten secara konkrit, sebagai sarana untuk menghubungkan diri dengan Tuhan/Ida Sang Hyang Widhi Wasa.

\subsubsection{Aspek Keindahan Dalam Kebertahanan Tari Rejang Sutri}

Semua benda atau peristiwa seni atau kesenian pada hakikatnya mengandung tiga aspek yang mendasar yakni (1) wujud atau rupa (appearance), (2) bobot atau sisi (content, substance), dan (3) penampilan atau penyajian (presentation). Wujud menyangkut bentuk (form) dan susunan atau struktur. Bobot mempunyai tiga aspek yaitu suasana (mood), gagasan (idea) dan pesan (message), sedangkan penampilan menyangkut tiga unsur yaitu bakat (tallent), keterampilan (skill) dan sarana atau media (Djelantik, 1999:17-18).

Sebuah aktivitas seni mempunyai fungsi horisontal yakni berusaha menghibur masyarakat dan fungsi vertikal, yakni ngayah kepada Ida Bhatara atau Tuhan. Jika kedua hal ini berhasil dilakoni, disitulah seorang seniman dikatakan metaksu. Dengan demikian, sang seniman merasa telah menjalankan dharma bhaktinya untuk kemanusiaan yakni mautsaha agawe sukaning len (berusaha menyenangkan orang lain), yang pada giliranya agawe sukanikanang rat (membuat kesenangan jagathita) dengan falsafah Satyam atau Sat (kebenaran), Siwam atau Cit (kesucian) dan Sundaram atau Ananda (keindahan atau kebahagiaan); kebenaran yang suci dan seni/indah, kesucian yang benar dan seni/indah, seni/indah yang benar dan suci. Tri wisesa ini merupakan sukma dari kesenian Bali yang bercorak religius Hindu dan religius filosofis. Ini adalah konsep arts and peace pada pengertian yang luas.
Estetika Hindu adalah perpaduan antara wirasa (emosional atau rasa), wirama (irama), wiraga (olah tubuh), dan Wibawa (taksu). Tari Rejang Sutri mengandung semua itu untuk sebuah ekspresi ke-Tuhanan. Aspek Sundaram atau Ananda itu artinya aspek keindahan atau aspek kebahagiaan. Keindahan yang menyebabkan orang merasa berbahagia bahwa persembahan kepada Tuhan melalui tari Rejang Sutri yang juga harus diikuti dengan kesucian hati sehingga mampu memberikan kepuasan bhatin bagi masyarakat Desa Batuan sehingga menyebabkan kebahagiaan. Adapun aspek keindahan dalam Tari Rejang Sutri yaitu mencakup gerak, komposisi, kostum dan arena tempat ditarikannya Tari Rejang Sutri.

\subsubsection{Aspek Kebahagiaan Dalam Kebertahanan Tari Rejang Sutri}

Hartoko (1983: 16) dalam bukunya berjudul Manusia dan Seni, memberi gambaran bahwa estetika adalah cabang filsafat yang berurusan dengan keindahan baik menurut realitasnya maupun menurut pengalaman subjektif. Dengan demikian estetika tidak lagi semata bercorak filsafat, tetapi juga amat ilmiah. Objek pemahaman estetika tidak hanya membicarakan keindahan semata, tetapi juga meluas meliputi seni, pengalaman estetik serta seniman dengan segala aspeknya (Pramono,1982: 3 dalam Triguna, 2003: 14).

Terkait dengan aspek kebahagiaan atau Ananda atau Sundaram dari tari Rejang Sutri di Desa Batuan mengacu pada konsep Satyam atau Sat (kebenaran), Siwam atau Cit (kesucian) dan sundaram atau Ananda (keindahan/kebahagiaan).

1. Satyam atau Sat (Kebenaran)

Tari Rejang Sutri yang dipentaskan merupakan suatu kebenaran karena hal tersebut telah termuat dalam susastra agama Hindu melalui Lontar-lontar, Babad, Purana, Prasasti dan lain sebagainya. Satyam ini mencakup nilai kejujuran, ketulusan dan kesungguhan hati dari orang yang menarikan dan penabuh gambelan. Dengan demikian dalam menarikan tari Rejang Sutri seyogyanya dilaksanakan dengan penuh rasa 
kejujuran, ketulusikhlasan dan niat yang sungguh-sungguh agar mendapat tuntunan dari yang tidak benar (asat) menjadi benar (sat): Asato ma satgamaya.

\section{Siwam atau Cit (Kesucian)}

Semua yang suci bersumber dari yang Mahasuci. Kesucian itu tidak akan dapat dipengaruhi oleh tempatnya bagaikan air yang tidak akan keruh karena tempatnya.Pementasan tari Rejang Sutri dilandasi dengan hati yang suci yang diimplementasikan melalui sikap dari orang yang menarikan dan memainkan gambelan. Apabila lahir dan batin telah suci maka apapun yang akan dikerjakan akan menghasilkan yang suci pula.

3. Sundaram atau Ananda (Keindahan, Kebahagiaan)

Keindahan merupakan hal yang mutlak diperlukan oleh rasa sehingga menimbulkan kebahagiaan, namun tetap tidak bisa terlepas dari kesucian yaitu Cit atau Siwam dan kebenaran itu sendiri yaitu Sat atau Satwam. Sesuatu yang dirasa dapat memberikan rasa indah maka disebut keindahan. Keindahan ini tercipta karena adanya krida Tuhan yang tertuang dalam konsep tarian Siwanatharaja. Sehingga Siwa adalah Hyang-hyangning Kalangwan.

Menurut Jro Mangku I Wayan Suda (Wawancara, 3 Juli 2020) mengatakan bahwa tari Rejang Sutri di Desa Batuan bila dikaji secara mendalam dan esensinya merupakan suatu karya seni musik dan tari yang melahirkan suatu perasaan keindahan yang menimbulkan kebahagiaan dalam suasana kesucian dan kesakralan.

Berdasarkan pendapat informan di atas, dapat dipahami secara praktek keagamaan Hindu Bali tidak bisa dipisahkan dengan segala macam upacara/ritual yang dilaksanakan. Semua bentuk seni akan teradopsi dengan sempurna menjadi sesuatu yang harmonis sehingga menghasilkan sebuah garapan seni spiritual yang mempunyai estetika tinggi sehingga menjadi lengut, adung, pangus, serta mataksu. Dengan demikian aspek kebahagian pun akan tercapai sebagai klimak kepuasan bathin tertinggi yang merupakan persatuan dari tiga Wisesa, yaitu Satyam, Siwam, dan Sundaram atau Sat, Cit, Ananda yang menyentuh kesan atau rasa lango. Sehingga masyarakat Desa Batuan hidup dalam keselamatan, kesejahteraan dan kedamaian.

\section{KESIMPULAN}

1. Masih bertahannya tari Rejang Sutri di Desa Batuan Tidak terlepas dari kepercayaan masyarakat Desa Batuan dan menjadikan tari Rejang Sutri sebagai Sradha Bhakti masyarakat Desa Batuan dimana keterkaitan kepercayaan kepada Tuhan sebagai kebenaran yang sejati atau Sat atau Satyam yang diwujudkan dalam bentuk persembahan sakral yaitu tari Rejang Sutri Masyarakat Desa Batuan meyakini bahwa dengan menjadikan kesenian sebagai suatu persembahan dan yadnya untuk mendekatkan diri dengan Tuhan (Ida Sang Hyang Widhi Wasa). Sesuai dengan dasar keyakinan agama Hindu yang dikenal dengan istilah Srada yang terdiri dari lima bagian yaitu Panca Srada .Salah satu srada tersebut yang sangat terkait adalah srada yang pertama yaitu percaya dengan adanya Brahman. Masyarakat Desa Batuan meyakini bahwa dengan pementasan tari Rejang Sutri merupakan sarana persembahan yang dapat menolak bala atau menangkal wabah penyakit. Sehingga tari Rejang Sutri masih bertahan keberlanjutannya karena menyagkut Sat atau Satyam yang berarti kebenaran sejati.

2. Yang berkontribusi terhadap bertahannya tari Rejang Sutri di Desa Batuan yaitu Prajuru Desa Adat Batuan sebagai pendukung tari Rejang Sutri yang dalam upaya pelestariannya tari Rejang Sutri telah tertuang dalam Awig-awig Desa Adat Batuan dan menjadi kesepakatan bersama seluruh Krama Desa Adat Batuan dan anggota masyarakat sebagai pendukung tari Rejang Sutri di dalam kebertahanan/ keberlanjutannya. Karena tari Rejang Sutri sebagai warisan budaya seni sakral Desa Batuan. Jadi dengan pementasan tari Rejang Sutri di Desa Batuan, masyarakat Desa Batuan telah mendukung kebertahanan tari Rejang Sutri sebagai persembahan sakral dan suci yang menempatkan Siwam atau Cit yang 
artinya kesucian, kejujuran, kesujatian sebagai hal yang sangat penting dan tidak bisa terlepas dari Satyam atau Sat yang artinya kebenaran sejati begitupula terkait dengan Sundaram atau Ananda yang berarti keindahan, kebahagiaan yang oleh masyarakat Desa Batuan di wujudkan dalam pementasan tari Rejang Sutri.

3. Cara mempertahankan tari Rejang Sutri di Desa Batuan yaitu dengan cara pewarisan dari generasi ke generasi karena tari Rejang Sutri mengandung aspek penolak bala, aspek ritual/upacara, dan aspek keindahan yang menyangkut gerak, komposisi, kostum, arena serta aspek kebahagiaan dalam kebertahanan tari Rejang Sutri dimana masyarakat Desa Batuan masih tetap mempertahankan tari Rejang Sutri karena sangat terkait dengan aspek Satyam atau Sat (kebenaran), Siwam atau Cit (kesucian) dan Sundaram atau Ananda (keindahan/kebahagiaan). Karena dalam persembahan suci di dalam menuju kebenaran tercapai sebuah kebahagiaan dari masyarakat Desa Batuan, sehingga mereka hidup dalam keselamatan, kesejahteraan dan kedamaian.

\section{DAFTAR PUSTAKA}

Bandem, I Made. 1985. Ensiklopedi Tari Bali. Cetakan Pertama. Denpasar: Akademi Seni Tari Indonesia (ASTI).

Bandem, I Made. 1996. Etnologi Tari Bali. Yogyakarta : Kanisius.

Dherana. 1982. Konsepsi Desa Pakraman di Bali. Denpasar : Upada Sastra.

Djelantik, A.A. Made. 1999. Estetika Sebuah Pengantar. Bandung : Masyarakat Seni Pertunjukan Indonesia.
Pudja, Gede. 1984. Sradha. Jakarta : Mayasari.

Pudja, Gede. 1993. Bhagavadgita (Pancama Weda). Jakarta : Hanuman Sakti.

Radhakrishnan. S. 2000. Pencarian Kebenaran. Penerjemah Tri Budhi Sastrio. Denpasar : Hindu Centre.

Sura, I Gede. 1994. Agama Hindu Sebuah Pengantar. Denpasar : CV Kayumas Agung.

Tim Penyusun. Undang-Undang RI No.20 Tahun 2003. Tentang Sistem Pendidikan Nasional. Surabaya : Karina.

Tim Penyusun. 1986/1987. Ensiklopedi Pewayangan Bali. Denpasar : Pemerintah Daerah Bali.

Tim Penyusun, 2003. Panca Yadnya (Dewa Yadnya, Butha Yadnya, Rsi Yadnya, Pitra Yadnya, dan Manusa Yadnya). Denpasar : Kegiatan Peningkatan Sarana Prasarana Kehidupan Beragama.

Tim Penyusun, 1993. Desa Adat dan Kepariwisataan di Bali, Proyek Pemantapan Lembaga Adat Daerah Tingkat I Denpasar.

Titib, I Made. 2003. Teologi dan SimbolSimbol dalam Agama Hindu, Surabaya : Paramita.

Triguna, Ida Bagus Yuda. 2003. Estetika Hindu dan Pembaguan Bali, Denpasar : Program Maister Ilmu Agama dan Kebudayaan Universitas Hindu Indonesia Bekerjasama dengan Penerbit widya Dharma. 